\title{
A Comparative Clinical Study on Renal Calculi - An Ayurvedic Perspective
}

\author{
Dr. K. V. Chakradhar \\ (PG Scholar, Department of Shalya - Ayurvedic General Surgery, S.V. Ayurvedic Medical College/ \\ Dr.NTRUniversity of Health Sciences, Vijayawada, India)
}

\begin{abstract}
From the study of ancient surgical text Sushruta samhita, itbecomes evident that the urological problems form an important part of medical sciences.Among all the urinary problems described in Ayurveda texts, there is one variety where both the medicinal and the surgical treatments are advised and agreed upon by all the Surgeons and this entity is the Renal Calculi.Further according to modern science the formation of stone in urinary system is one of the main problems of urology. The cause and mechanism of their formation is still uncertain. On one hand surprisingly stone does not always form when such factors are present and on the other hand stones may develop when factors are apparently absent too. Furthermore renal calculus occurs in both the sexes at all the ages but commonly in the 3rd and 4th decades, stone in kidney or in ureter is probably little more frequent in men than women. Renalcalculi an agonizing complex disorderpresenting with severe colicky pain radiating to loin to groin, burningmicturition,dysuria.Sushruta (800BC), Fatherof Indian Surgery considered this Renal Calculi, one among AshtaMahagada, theeight incurable diseases on globe. The average prevalence rate in India ranging around $3.4 \%$ at Mean age group of 20-40 years. Available modern treatment procedures like Forcible Diuresisand Lithotripsy solve the problems temporarily but still recurrences are very common after stopping the treatment. The Purpose of this Paper is an attempt to pave for a solution in breaking the nut for resolving the Clinical Barrier. Probably this development makes the Researchers and Clinicians of this Speciality to adopt a Standard mode of Regimen in conquering this Renal Disorder.
\end{abstract}

Keywords: Renal calculi, Alkali preparation of Barley, PM Compound.

\section{Introduction}

Ayyurveda, the System of Indian medicine and science of life deals with the wellbeing of mankind. The three great authors namely Charaka, Suśruta and Vāgbhata followed the scientific methods of study to enhance the perception of Āyurveda towards humanity. Renal Calculi is known to mankind since times immemorial. Clinical features of the disease are described even in Vedās, the oldest repositories of human knowledge. Suśruta the father of surgery explained urinary calculus under the heading of Ashmari in details including etiological factors, classification, symptomatology, pathology, complications and its management in a most scientific manner. This disease is dreadful and hence considered one of the 'Mahāgadās' by Suśruta, may be owing to its potentiality to disturb the anatomy and physiology of urinary system. Suśruta, the pioneer in the art of surgery have practicedextensive operative surgery on all the system of the body. Hirschberg also mentioned that "the Indians knew and practiced the indigenous operation which always remain unknown to the Greeks and which we the Europeans learn only from them with surprise". The old bladder stone is reported at "ELAMARAH" in Upper Egypt, dated about 4800 BC, shows that humans of ancient time were undoubtedly affected with the disease Aśmari just as humans are now. Rggveda and Atharavaveda (2000 - 5000 BC) also mentioned the stone and advise people not to ride a horse, Charaka has advised medical management and Suśruta advised both conservative and surgical removal of stone through perineal root cystolithotomy.

The urinary stone have peculiar tendency of recurrence despite of their surgical removal. Once a stone formed, is always stone former. Therefore, surgery can only be a part of treatment, but not the sheer treatment. To avoid the incidence of recurrence after surgical removal of stone and in search of an effective conservative treatment the present work has been undertaken. An alarming rise in the incidence of urolithiasis coupled with a motivation provided by W.H.O. (World Health Organization) to explore the possibility of discovering cure on traditional line has created an impetus for further research in the light of Āyurvedic knowledge. As far as Renal Calculi (urolithiasis) is concerned Department of Śalya, S.V.Ayurvedic college and Hospital, Tirupati is putting efforts to come with a positive answer to this disease.

II. AimsOf The Study

2.1 To study the LITHOTRIPSIC ACTIVITY of Alkali preparation of Barley given in Paaneyakshara form [internally]. 
2.2 To study the disease Renal Calculi in terms of its etiopathogenesis, clinical manifestations with possible correlation to the description available in modern and Ayurveda medicine for Urolithiasis.

2.3 To find out the efficacy of trial drug in the management of Renal Calculi.

\section{Settings And Design} patients.

All the patients in the present study have been divided into two groups, each group containing 10

Group I: 10 patients (Alkali preparation of Barley -Yava kshara in paneeya kshara form) - TEST DRUG

Group II: 10 patients (PM Compound) - STANDARD CONTROL

\section{Methods And Material}

Total 20 patients were taken up for study from P.G. Department of Ayurveda General Surgery,

S.V. AyurvedaMedicalCollegeTirupati, after subjecting to selection criteria based on Inclusion and Exclusion criteria. 10 patients were given Alkali preparation of Barley $400 \mathrm{mg}$ twice in a week internally mixed with $200 \mathrm{ml}$ of Sterile Water, before food in the morning in a span of 4-6 weeks. Remaining 10 patients were given P.M Compound (A compound prepared out of Punarnavadi mandoora, Gokshuradi guggulu, Chandraprabha Vati in equal quantities) internally with dosage of $500 \mathrm{mg}$ BID schedule for a period of 4-6 weeks. Both the groups were subjected for a Subjective parameters (Pain, Burning micturition, Dysuria, Tenderness at renal angle) and Objective parameters (X-ray KUB, USG KUB) following a standard proforma. USG-KUB determines size, consistency and location of calculus and it place an important role in assessing Objective criteria.

Statistical analysis used: Two Sample t-Test is used for statistical analysis.

\subsection{Subjects and Methods} patients.

All the patients in the present study have been divided into two groups, each group containing 10

Group I: 10 patients (Alkali preparation of Barley -Yava kshara in paneeya kshara Form) - TEST DRUG

Group II: 10 patients (PM Compound) - STANDARD CONTROL

\subsection{Parameters}

\subsubsection{Subjective Parameters:}

Assessment of the Therapy is done according to the relief observed in the signs and symptoms with the help of scoring pattern which is prepared according to classical Ayurveda and modern texts.

\subsubsection{Objective Parameters:}

Based on various investigations like urine, blood, biochemical examination, X-Ray (KUB), USG (KUB) are carried before and after treatment.

\section{Inclusion Criteria}

5.1) Age: Between 15 to 60 years

5.2) Sex: Either sex

5.3) Radiological evidence of stone (up to8 $\mathrm{mm}$ ) in Kidney, Ureter and Urinary Bladder.

\section{Exclusion Criteria:}

6.1) Patients with age below 15 years and above 60 years.

6.2) Stone size more than $10 \mathrm{~mm}$.

6.3) Impacted stone.

6.4) Gross Hydronephrosis.

6.5) Pyelonephritis.

6.6) Uncontrolled Diabetic Mellitus and Hypertension

6.7) Malignancy.

6.8) Impaired Renal Function.

6.9) Poorly Functioning Kidney.

6.10) Patients with obstruction in urinary passage.

6.11) Patients with known Metabolic abnormality for calculus formation.

6.12) Any other complication of calculus.

6.13) Patients undergoing treatment for any other serious illness 
In both the groups all the patients were instructed to follow theirnormal dietetics and to maintain regular intervals in between the two meals.All the patients were advised to resist from all the diets which are directly orindirectly contributory to the formation of stone. Further all the patientswere instructed to take plenty of water.

\section{Subjective Criteria}

Assessment of the therapy was done according to the relief observedin the signs and symptoms, with the help of scoring pattern.

General Symptoms Score:

$\square$ Complete absence of the signs and symptoms - 0

$\square$ Mild degree of the signs and symptoms - 1

$\square$ Moderate degree of the signs and symptoms - 2

$\checkmark$ Severe degree of the signs and symptoms - 3

$\square$ Acute condition of signs and symptoms - 4

\section{Objective Criteria}

Based on various investigation like urine, blood, biochemicalexamination, x-ray (KUB), USG (KUB), done before and after treatment. The statistical analysis was done of these score before starting the treatment and after completion of 60 days course.The details of the scores adopted for the chief signs and symptoms inthe present study were as follows -

8.1Pain:

$\square$ No pain- 0

$\square$ Occasional pain did not require treatment - 1

$\square$ Occasional pain but, required treatment - 2

$\square$ Constant dull ache pain, required treatment - 3

$\square$ Severe constant pain, but did not show relief even after treatment-4

\subsection{Burning Micturition:}

$\square$ No burning micturition - 0

Occasional burning micturition - 1

$\square$ Occasional burning micturition, required treatment - 2

$\square$ Constant burning micturition required treatment - 3

$\square$ Constant severe burning micturition but did not show relief even after

Treatment - 4

\subsection{Dysuria:}

$\square$ No dysuria - 0

Occasional dysuria - 1

$\square$ Occasional dysuria which require treatment - 2

Constant dysuria which require treatment - 3

$\square$ Constant severe dysuria but did not show relief

Even after treatment - 4

8.4 Tenderness in Renal Angle:

$\checkmark$ No tenderness - 0

$\checkmark$ Mild tenderness - 1

$\square$ Moderate tenderness - 2

$\square$ Severe tenderness - 3

$\square$ Acute tenderness -4

8.5 Haematuria: On the basis of microscopic urine analysis
$\checkmark$ No RBC/Hpf - 0
$\square 0-5 \mathrm{RBC} / \mathrm{Hpf}-1$
$\square 6-10 \mathrm{RBC} / \mathrm{Hpf}-2$
$\square 11-15 \mathrm{RBC} / \mathrm{Hpf}-3$
$716 \mathrm{RBC} / \mathrm{Hpf}-4$

8.6 Pus Cells: On the basis of microscopic urine analysis
No pus cells/Hpf - 0
$\square 0-5$ pus cells/Hpf - 1
$\square-10$ pus cells/Hpf -2
$11-15$ pus cells/Hpf - 3
$\square>16$ pus cells/Hpf -4 . 
And like wise other clinical symptoms were assessed on the basis of severity, this was done before treatment and after treatment andimprovement was assessed on percentage basis.

\section{Criteria For Total Effect Of Therapy}

For the assessment of the total effect of the therapy following fourcategories were taken into considerations.

\subsection{Cured $-76 \%$ to $100 \%$}

Complete relief in subjective signs and symptoms.

$\square$ Absence of any calculus in urinary tract with radiological evidence.

\subsection{Markedly Improved $-51 \%$ to $75 \%$}

$\square$ Relief in subjective signs and symptoms

$\square$ Downward movement or partial disintegration of Renal Calculi withradiological evidence.

9.3 Improved - $26 \%$ to $50 \%$

$\square$ Relief in signs and symptoms

$\square$ Without any change in size of stone confirmed with radiologicalevidence.

\subsection{Unchanged - Up to $25 \%$}

$\square$ Relief in subjective sign and symptoms.

\section{X. $\quad$ Follow Up}

All the patients who were studied under this clinical trial aftercompletion of treatment for prescribed period were instructed to haveregular check up at the interval of 7 to 15 days for the period of 3 months $(90$ days). During this follow up study period patients were examinedthoroughly for the recurrence of either signs and symptoms of stones.Further, they were instructed about Pathya-Apathya.

\section{Selection Of The Drug}

YAVAKŞĀRA - Alkali preparation of barley

Latin name: Hordeumvulgare

Family: Gramineae

Properties:

$\square$ Rasa:Kațu

$\square$ Guña:Laghu, Snigdha

$\square$ Virya:Uşñ

$\square$ Vipāka:Kațu

$\square$ Doşaghnatā:KaphaVātaŚāmaka

11.1 Pharmacological Action : This drug is useful in the pathogenesis likeAmlapitta, Aśmari, Mūtrakṛccra, Udaraśūla, Gulma, Arśa.

Chemical Constituents: The substance contains potassium chloride, potassium sulphate, potassium bicarbonate and potassium carbonate.

N.B.: Toxic doses of alkalis or when continued in large doses causealkalosis giving rise to headache, vomiting, general prostration and possiblyTetany due to diminished Calcium in plasma (R. Gosh).

\section{$\square$ BARLEY}

Latin name :Hordeumvulgare

Family :Gramineae

Gaņa:DhānyaVarga (B. P.)

Part used: Whole plant

\section{Properties:}

$\square$ Rasa:Kaśāya, Madhura

$\square$ Guņa: Guru, Rukşa, Mṛdu, Piccila

$\square$ Virya:Śita

$\square$ Vipāka:Kațu

$\square$ Doşaghnatā:Kapha-pittahara

Pharmacological Action:Medohara, Pramehahara, Tṛsāhara, Kaphahara,

Śramahara, RaktapittaPrasadaka, Atisāra, Mūtrakṛcchra.

Chemical Constituents: Yava contains carbohydrates, protein, minerals

like calcium, iron, etc.

11.2 Alkali preparation of Barley (Kşāra Nirmāņa Vidhi): 
This is an alkali substance, which is being prepared from the breadsof Barley with the procedure of Kşāra Nirmāņa Vidhi.Dry Yava Pancāňga should be divided into small pieces, ignited by sesamum stalks (Tila) with pebbles of limestone. When the fire has burntout, the ash and the slake lime should be collected separately. Then one Drona of the ash should be dissolved in six Dronāas of water and filtered 21 times and should be treated on fire in a big pan, while it is slowly stirred bya ladle. When it becomes clear, red, sharp and slimy, it should be filteredthrough a wide piece of cloth and the filtrate should be placed again on fireafter removing the separated residue.

\section{Pm Compound}

Acompound prepared out of Punarnavadimandoora50gms, Gokshuradiguggulu 50gms, ChandraprabhaVati 50 Gms in equal quantities.

12.1\} PunarnavadiMandoora: ingredients are punarnava, trivrit, maricha, pippali, vidanga,kushta,pippalimula, musta, mandura,gomutra

12.2\} Gokshuradiguggulu: ingredients are gokshura, pura, maricha, pippali, haritaki, vibhitaki, amalaki, musta 12.3\} Chandraprabhavati: ingredients are chandraprabha, vacha, musta, bhunimba, amrita, daruka, ativisha,vidanga, danti , patraka, eranda, sita, silajitu, guggulu etc.,

Both the Test drugs were prepared at the Pharmacy of S.V. Ayurveda Pharmacy, Tirupati.

\section{Analytical Study}

The analytical study of the prepared Alkali preparation of barleyandPM Compound were undertaken in the pharmaceutical laboratory of S.V.AyurvedaMedicalCollege, Tirupati. The details are described as below

\subsection{Analysis:}

\begin{tabular}{|c|c|c|}
\hline & Alkali preparation of Barley & PM Compound \\
\hline Specific Gravity & 1.019 & 1.016 \\
\hline$p H$ & 6.73 & 6.38 \\
\hline
\end{tabular}

\section{Results}

In the present clinical study total 28 patients were registered whichwere divided into two groups.

Group I: Treated withAlkali preparation of Barleyinpaneeyakshara form orally comprised of 15 patients.Amongst them 05 patients left the treatment against medical advice.

Group II: Treated with PM Compound orally comprised of 13 patients.Amongst them 03 patients left the treatment against medical advice.

\begin{tabular}{|c|c|c|c|}
\hline No. of Patients & Group I & Group II & Total \\
\hline Registered & 15 & 13 & 28 \\
\hline Completed & 10 & 10 & 20 \\
\hline LAMA* & 05 & 03 & 08 \\
\hline
\end{tabular}

*LAMA - Left Against Medical Advice

Table - 1: Age wise distribution of 28 patients of Renal Calculi

\begin{tabular}{|c|c|c|c|c|}
\hline Age & Group I & Group II & Total pts. & $\%$ \\
\hline 21-30 years & 04 & 01 & 05 & 17.86 \\
\hline 31-41 years & 07 & 05 & 12 & 42.86 \\
\hline 41-50 years & 02 & 03 & 05 & 17.86 \\
\hline 51-60 years & 01 & 02 & 03 & 10.71 \\
\hline Above 60 yrs & 01 & 02 & 03 & 10.71 \\
\hline
\end{tabular}

It was found that maximum number of patients i.e. $42.86 \%$ belongedto age group of $31-40$ years, while $17.86 \%$ patients belonged to $21-30$ years and $41-50$ years of age group each, and $10.71 \%$ of patients belonged to $51-60$ and above 60 years of age group.

Table - 2: Sex wise distribution of 28 patients of Renal Calculi

\begin{tabular}{|c|c|c|c|c|}
\hline Sex & Group I & Group II & Total pts. & $\%$ \\
\hline Male & 12 & 08 & 20 & 71.43 \\
\hline Female & 03 & 05 & 08 & 28.57 \\
\hline
\end{tabular}

In this series, the maximum numbers of patients i.e. $71.43 \%$ were 
male while rest of the patients i.e. $28.57 \%$ were female.

Table -3: Socio-economic status wise distribution of 28 patients of Renal Calculi

\begin{tabular}{|c|c|c|c|c|}
\hline & Group I & Group II & Total pts. & $\%$ \\
\hline Poor & 01 & 01 & 02 & 07.14 \\
\hline Lower middle & 06 & 07 & 13 & 46.43 \\
\hline Middle & 06 & 05 & 11 & 39.29 \\
\hline Upper middle & 02 & 00 & 02 & 07.14 \\
\hline Rich & 00 & 00 & 00 & 00.00 \\
\hline
\end{tabular}

Table shows that maximum i.e. $46.43 \%$ patients were belonging tolower middle class, $39.29 \%$ were from middle class and minimum $07.14 \%$ each were belonging to poor sector of society and upper middle class.

Table - 4: Diet wise distribution of 28 patients of Renal Calculi

\begin{tabular}{|c|c|c|c|c|}
\hline Diet & Group I & Group II & Total pts. & $\%$ \\
\hline Vegetarian & 07 & 08 & 15 & 53.57 \\
\hline Mixed & 08 & 05 & 13 & 46. \\
\hline
\end{tabular}

Table - 5:ŚāriraPrakṛti wise distribution of 28 patients of Renal Calculi

\begin{tabular}{|c|c|c|c|c|}
\hline Saririkaprakriti & Group I & Group II & Total pts. & $\%$ \\
\hline Vata -pitta & 05 & 06 & 11 & 39.29 \\
\hline Kapha-pitta & 02 & 02 & 04 & 14.29 \\
\hline Vata-kapha & 08 & 05 & 13 & 46.43 \\
\hline
\end{tabular}

ŚāriraPrakṛti wise distribution indicates that most of the patients i.e.46.43\% were having VātakaphaŚāriraPrakṛti, 39.29\% patients werehaving Vāta-pitta and remaining $14.29 \%$ patients had Kapha-pitta SāriraPrakṛti.

Table-6: Chief complaints wise distribution of 28 pts. Of Renal Calculi

\begin{tabular}{|c|c|c|c|c|}
\hline Chief complaint & Group I & Group II & Total pts & $\%$ \\
\hline Nabhivedan & 12 & 11 & 23 & 82.14 \\
\hline Bastivedan & 08 & 08 & 16 & 57.14 \\
\hline Sevanivedan & 06 & 00 & 06 & 21.43 \\
\hline Mehanvedan & 05 & 02 & 07 & 25.00 \\
\hline Mutradharsanga & 14 & 06 & 20 & 71.43 \\
\hline Sarudhiramutrata & 05 & 04 & 09 & 32.14 \\
\hline Mutravikirana & 00 & 00 & 00 & 00 \\
\hline Gomedaprakasam & 04 & 02 & 06 & 21.43 \\
\hline Atiavilamutrata & 12 & 12 & 24 & 85.71 \\
\hline Sasikta & 00 & 00 & 00 & 00 \\
\hline Visirnadhara & 00 & 00 & 00 & 00 \\
\hline Mrudnatimedhra & 00 & 00 & 00 & 00 \\
\hline
\end{tabular}

Table shows that maximum i.e. $85.71 \%$ patients were having AtiĀvilaMūtratā, $82.14 \%$ were suffering from NābhiVedanā, $71.43 \%$ patients werehavingMūtradhāraSanga, $57.14 \%$ patients were having BastiVedanā,32.14\% patients were having SarudhiraMūtratā, $25 \%$ patients were havingMehanaVedanā and $21.43 \%$ each were having SevaniVedanā and GomedaPrakāśam.

Table-7: Modern parameters wise distribution of 28 pts. Of Renal calculi

\begin{tabular}{|c|c|c|c|c|}
\hline Modern parameters & Group I & Group II & Total no. of patients & $\%$ \\
\hline Pain & 15 & 13 & 28 & 100 \\
\hline Burning micturition & 11 & 11 & 22 & 78.57 \\
\hline Haematuria & 04 & 05 & 09 & 32.14 \\
\hline Dysuria & 10 & 08 & 18 & 64.29 \\
\hline Nausea\& vomiting & 00 & 00 & 00 & 00 \\
\hline Fever & 00 & 00 & 00 & 00 \\
\hline Tenderness in renal angle & 06 & 04 & 10 & 35.71 \\
\hline
\end{tabular}


All the 28 patients of Renal Calculi(Mūtrāśmari) were having the pain, $78.57 \%$ patients were having burning micturition, $64.29 \%$ patients were having dysuria, $35.71 \%$ patients were having tenderness in renal angle and $32.14 \%$ patients had haematuria

Table - 8: Size of stone wise distribution of 28 patients of Renal calculi

\begin{tabular}{|c|c|c|c|c|}
\hline Size of stone & Group I & Group II & Total patients & $\%$ \\
\hline$<0.5 \mathrm{~cm}$ & 00 & 02 & 02 & 11.11 \\
\hline Above $0.5 \mathrm{~cm}$ & 10 & 06 & 16 & 89.89 \\
\hline
\end{tabular}

Table - 9: Site of stone wise distribution of 28 patients of Renal calculi

\begin{tabular}{|l|c|c|c|c|}
\hline Site of stone & Group I & Group II & Total & $\%$ \\
\hline Kidney & 10 & 06 & 16 & 57.14 \\
\hline Ureter & 05 & 03 & 08 & 28.57 \\
\hline Bladder & 03 & 04 & 07 & 25.00 \\
\hline \multicolumn{1}{|c|}{ Urethra } & 00 & 00 & 00 & 00 \\
\hline
\end{tabular}

*some patients were having more than one stone at different sites. On considering the site of stone, it was found that maximum i.e.57.14\% patients were having stone in kidney, while $28.57 \%$ had in ureterand only $25 \%$ patients had bladder stones.

Table - 10: Number of stone wise distribution of 28 patients ofRenal calculi

\begin{tabular}{|c|c|c|c|c|}
\hline Number of stone & Group I & Group II & Total & $\%$ \\
\hline Single & 08 & 11 & 19 & 67.86 \\
\hline Multiple & 07 & 02 & 09 & 32.14 \\
\hline
\end{tabular}

Table -11: Bilateral - unilateral wise distribution of 28 patients ofRenal calculi

\begin{tabular}{|c|c|c|c|c|}
\hline & Group I & Group II & Total & $\%$ \\
\hline Bilateral & 13 & 11 & 24 & 85.71 \\
\hline Unilateral & 02 & 02 & 04 & 14.29 \\
\hline
\end{tabular}

It is clearly evident from the data of the present series that majority of the patients i.e. $85.71 \%$ were having unilateral stone while only $14.29 \%$ were having bilateral stones.

Table -12: Variety of stone wise distribution of 28 patients ofRenal calculi

\begin{tabular}{|c|c|c|c|c|}
\hline Variety of stone & Group I & Group II & Total & $\%$ \\
\hline Vataja & 09 & 09 & 18 & 64.29 \\
\hline Pittaja & 02 & 01 & 03 & 10.71 \\
\hline Kaphaja & 04 & 03 & 07 & 25.00 \\
\hline
\end{tabular}

It is evident from the above table that maximum $64.29 \%$ patients hadVātaja type of Aśmari, while $25 \%$ patients were having Kaphaja type ofAśmari, whereas only $10.71 \%$ patients were having Pittaja type of Aśmari.

\section{XV. $\quad$ Effect Of Therapies}

In the present study, 28 patients were registered out of which 8Patients left treatment against medical advice. Remaining of 20 patientscompleted the full course of the treatment. They were categorized into twogroups and studied as follows----

Alkali preparation of barley (Group - I: Treated Group):

\begin{tabular}{|c|c|c|c|c|c|c|c|}
\hline Clinical features & B.T. & A.T. & $\%$ & SD & $\mathrm{SE}$ & " $\mathrm{t}$ " & $\mathrm{P}$ \\
\hline Nabhivedana & 2.20 & 1.00 & 54.55 & 0.78 & 0.25 & 4.80 & $<0.001$ \\
\hline Bastiveclana & 1.30 & 0.60 & 53.85 & 0.82 & 0.26 & 2.69 & $<0.01$ \\
\hline Sexanivedana & 1.10 & 0.60 & 45.45 & 0.53 & 0.17 & 2.94 & $<0.01$ \\
\hline Mehanyedana & 0.80 & 0.40 & 50.00 & 0.70 & 0.22 & 1.81 & $<0.05$ \\
\hline Mutracharasanga & 2.10 & 1.10 & 47.62 & 0.66 & 0.21 & 4.76 & $<0.001$ \\
\hline Saruchiramutrata & 0.70 & 0.30 & 57.14 & 0.52 & 0.16 & 2.50 & $<0.01$ \\
\hline Gomeclaprakasa & 0.70 & 0.10 & 85.71 & 0.84 & 0.27 & 2.22 & $<0.05$ \\
\hline Atiavilamutrata. & 2.00 & 0.90 & 55.00 & 0.99 & 0.31 & 3.55 & $<0.001$ \\
\hline
\end{tabular}


After completion of the therapy of Alkali preparation of barleyin Paneeya kshara form for six weeks , its effect on the clinical features were observed as presented in table.Alkali preparation of Barleyprovided highly significant relief in Nābhivedanā (umbilical pain) (54.55\%), MūtradhāraSanga (47.62\%) and AtiĀvilamūtratā (55.00\%). Effect wasstatistically significant in BastiVedanā (53.85\%),

SevaniVedanā (45.45\%) andSarudhiraMūtratā(Heamaturia) $(57.14 \%)$, followed by insignificant relief in MehanaVedanā (50.00\%) and GomedaPrakāśam (85.71\%).

Table -14: Effect of therapy on clinical features (acc. to modern) in 10 patients of Renal calculi

\begin{tabular}{|c|c|c|c|c|c|c|c|}
\hline & \multicolumn{2}{|c|}{ MEAN } & & & & & \\
\hline Clinical features & B.T. & A.T. & $\%$ & $\mathrm{SD}$ & $\mathrm{SE}$ & 't' & $P$ \\
\hline Pain & 3.50 & 1.90 & 45.71 & 0.80 & 0.25 & 6.40 & $<0.001$ \\
\hline $\begin{array}{l}\text { Burning } \\
\text { micturition }\end{array}$ & 2.60 & 0.50 & 80.76 & 1.10 & 0.35 & 6.00 & $<0.001$ \\
\hline Haematuria & 0.00 & 0.40 & 0.00 & $\ldots$ & $\ldots$ & $\ldots$ & NS \\
\hline Dysuria & 2.00 & 1.40 & 30.00 & 0.80 & 0.25 & 2.40 & $<0.01$ \\
\hline Pyuria & 1.00 & 1.10 & 10.00 & $\ldots$ & $\ldots$ & $\ldots$ & $\mathrm{NS}$ \\
\hline $\begin{array}{l}\text { Tenderness at } \\
\text { Renal Angle }\end{array}$ & 0.90 & 0.30 & 66.66 & 0.70 & 0.22 & 2.73 & $<0.01$ \\
\hline
\end{tabular}

After completion of the therapy of Alkali preparation of barleyin Paneeya kshara for six weeks itseffect on the clinical features were observed as presented in table. Alkali preparation of barleyprovided highly significant relief in Pain $(45.71 \%)$ and burning micturition $(80.76 \%)$. Effect was statistically significant in Dysuria $(30.00 \%)$ and tenderness at renal angle $(66.66 \%)$, followed by insignificant relief in Haematuria and Pyuria.

PM COMPOUND (Group - II: Standard Control Group)

Table -15 : Effect of therapy on clinical features (Acc. to Ayurveda) of 10 patients of Renal calculi

\begin{tabular}{|c|c|c|c|c|c|c|c|}
\hline Clinical features & B.T. & A.T. & $\%$ & S.D. & S.E. & 't' & P \\
\hline Nabhivedana & 2.20 & 1.70 & 22.73 & 0.53 & 0.17 & 2.94 & $<0.01$ \\
\hline Bastivedana & 1.70 & 0.70 & 58.82 & 0.82 & 0.25 & 4.00 & $<0.001$ \\
\hline Mehanvedana & 0.40 & 0.10 & 75.00 & 0.67 & 0.21 & 1.43 & $<0.05$ \\
\hline Mutracharasang & 1.10 & 0.40 & 63.64 & 0.82 & 0.26 & 2.69 & $<0.01$ \\
\hline Saruchiramutrata & 0.80 & 0.30 & 62.50 & 0.71 & 0.22 & 2.27 & $<0.01$ \\
\hline Gomedapralasha. & 0.50 & 0.10 & 80.00 & 0.84 & 0.27 & 1.48 & $<0.05$ \\
\hline Atiavilamutrata & 1.60 & 1.00 & 37.50 & 0.70 & 0.22 & 2.73 & $<0.01$ \\
\hline
\end{tabular}

After completion of the therapy of PM Compound for six weeks, its effect on the clinical features was observed as presented in table.PM Compound provided highly significant relief in BastiVedana $(58.82 \%)$. Effect was statistically significant in NähhiVecanā (22.73\%) MütrachāraSanga (63.64\%), AtiAvilamutrata (37.50\%) and SaruchiraMūtratā (62.50\%), followed by insignificant relief in MehanaVedanā andGomedaPrakä́am.

Table -16: Effect of therapy on clinical features (acc. to modern) in 10 patients of Renal calculi

\begin{tabular}{|c|c|c|c|c|c|c|c|}
\hline \multicolumn{3}{|c|}{ MEAN } & \multicolumn{5}{|c|}{ (a) } \\
\hline Clinical features & B.T. & A.T. & $\%$ & S.D. & S.E. & 't' & $\mathrm{P}$ \\
\hline Pain & 3.40 & 1.50 & 55.88 & 0.57 & 0.18 & 10.56 & $<0.001$ \\
\hline $\begin{array}{l}\text { Burning } \\
\text { micturition }\end{array}$ & 2.00 & 1.60 & 20.00 & 0.53 & 0.17 & 2.94 & $<0.01$ \\
\hline Haematuria & 1.10 & 0.70 & 36.36 & 1.65 & 0.52 & 0.77 & $<0.05$ \\
\hline Dysuria & 1.40 & 0.60 & 57.14 & 0.79 & 0.25 & 3.20 & $<0.01$ \\
\hline Pyuria & 2.20 & 1.50 & 31.82 & 1.06 & 0.34 & 2.06 & $<0.05$ \\
\hline $\begin{array}{l}\text { Tenderness at } \\
\text { Renal Angle }\end{array}$ & 0.80 & 0.30 & 62.50 & 0.71 & 0.22 & 2.27 & $<0.01$ \\
\hline
\end{tabular}

After completion of the therapy of PM Compound for six weeks, its effect on the clinical features were observed as presented in table.PM Compound provided highly significant relief in Pain (55.88\%). Effectwas statistically significant in Burning micturition (20.00\%), Dysuria (57.14\%) and tenderness at renal angle $(62.50 \%)$, followed by insignificantrelief in Haematuria and Pyuria. 
Table -16 : Effect of therapy on stones at different site and size inboth the groups (I \& II)

\begin{tabular}{|c|c|c|c|c|c|}
\hline \multirow[t]{2}{*}{ SIZE(Diameter) } & & \multicolumn{4}{|c|}{ No. of patients } \\
\hline & SITE & Group I & Effect & Group II & Effect \\
\hline \multirow{4}{*}{$<0.5 \mathrm{Cm}$} & Kidney & 00 & - & 01 & $\mathrm{NC}-1$ \\
\hline & Ureter & 00 & & 02 & $\begin{array}{c}\text { EXP }-1 \\
\text { DM }-1\end{array}$ \\
\hline & Bladder & 00 & - & 01 & EXP - 1 \\
\hline & Urethra & 00 & 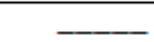 & 00 & 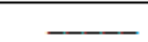 \\
\hline \multirow[t]{4}{*}{$>0.5 \mathrm{Cm}$} & Kidney & 06 & $\begin{array}{c}\text { EXP - } 1 \\
\text { DS- } 1 \\
\text { IS- } 1 \\
\text { NC }-1\end{array}$ & 05 & $\begin{array}{l}\text { DS - } 1 \\
\text { NC }-3\end{array}$ \\
\hline & Ureter & 04 & $\begin{array}{l}\operatorname{EXP}-1 \\
\text { NC }-1\end{array}$ & 01 & $\mathrm{NC}-1$ \\
\hline & Bladder & 01 & $\mathrm{NC}-1$ & 01 & $\mathrm{NC}-1$ \\
\hline & Urethra & 00 & 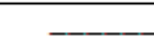 & 00 & - \\
\hline
\end{tabular}

*some patients were having more than one stone at different sites.

Key of observations -

NC: No change Exp.: Expelled

DM: Downward movement DS: Decrease in size

IS: Increase in size

It has been observed in group I (Alkali preparation of barley) that all the stonesWere $>0.5 \mathrm{~cm}$ in size, total 6 stones were found in kidney, out of them 3Expelled out, 1 decreased in size, 1 increased in size and in remaining 1 Stone no change was observed after the completion of the therapy. However in 4 ureteric stones, 2 were expelled out and in remaining 2 stones there were no change observed. In a bladder stone no change was observed.

In group II (PM Compound), it has been observed that total 4 stones were found in $<0.5 \mathrm{~cm}$ size out of them 1 kidney stone found with nochange, in 2 ureteric stone 1 was expelled out and another got downward movement, whereas a bladder stone was expelled out after the completion of treatment. It has been observed that total 7 stones were found in $>0.5 \mathrm{~cm}$ in size, amongst them 5 were in kidney, out of them 2 stones decreased in size and 3 stones remained unchanged. In a ureteric and a bladder stones no change was observed.

Table -17 : Effect of therapy on types of Asmari in 20 patients of Renal calculi

\begin{tabular}{|c|c|c|c|c|}
\hline \multirow[t]{2}{*}{ Variety/Effect } & \multicolumn{2}{|c|}{ Group I } & \multicolumn{2}{|c|}{ Group II } \\
\hline & No. of Pts. & $\%$ & No. of Pts. & $\%$ \\
\hline VATAJA ASHMARI & 06 & & 07 & \\
\hline Cured & 03 & 50.00 & 01 & 14.29 \\
\hline Markediy Improved & 01 & 16.67 & 00 & 00.00 \\
\hline Improved & 01 & 16.67 & 02 & 28.57 \\
\hline Unchanged & 01 & 16.67 & 04 & 57.14 \\
\hline PITTAJA ASHMARI & 02 & & 01 & \\
\hline Cured & 01 & 50.00 & 00 & 00.00 \\
\hline Markedily Improved & 01 & 50.00 & 01 & 100 \\
\hline Improved & 00 & 00.00 & 00 & 00.00 \\
\hline Unchanged & 00 & 00.00 & 00 & 00.00 \\
\hline KAPHAJA ASHMARI & 02 & & 02 & \\
\hline Cured & 00 & 00.00 & 00 & 00.00 \\
\hline Markedily Improved & 00 & 00.00 & 00 & 00.00 \\
\hline Improved & 01 & 50.00 & 02 & 100 \\
\hline Unchanged & 01 & 50.00 & 00 & 00.00 \\
\hline
\end{tabular}


In group I (Alkali preparation of barleygiven in paneeya kshara form ), out of 10 patients, 6patients were suffering from Vātaja type of Aśmari. Out of them 3 patients were observed cured (50\%), 1 markedly improved (16.67\%), 1 improved (16.67\%) and 1 found unchanged (16.67\%). In Pittaja type of Aśmari, out of 2 patients, 1patient cured (50\%) and 1 patient markedly improved (50\%). In Kaphaja type of Aśmari, out of 2 patients 1 improved (50\%) and 1 was found unchanged (50\%).

In group II (PM Compound), out of 10 patients, 7 patients were suffering from Vātaja type of Aśmari. Out of them 1 patient was observed cured (14.29\%), 2 improved (28.57\%) and 4 found unchanged (57.14\%). InPittaja type of Aśmari, 1 patient was observed as markedly improved (100\%) in Kaphaja type of Aśmari all the 2 patients were observed as improved $100 \%$.

Table -18 : Effect of therapy on types of Urelithiasis, in 20 patients sfenal calculi

\begin{tabular}{|c|c|c|c|c|}
\hline \multirow[t]{2}{*}{ Variety / Effect } & \multicolumn{2}{|c|}{ Group I } & \multicolumn{2}{|c|}{ Group II } \\
\hline & $\begin{array}{l}\text { No. of } \\
\text { Pts. }\end{array}$ & $\%$ & $\begin{array}{l}\text { No. of } \\
\text { Pts. }\end{array}$ & $\%$ \\
\hline KIDNEY STONE & 06 & & 06 & \\
\hline Cured & 02 & 33.33 & 00 & 00.00 \\
\hline Markedly Improved & 00 & 00.00 & 00 & 00.00 \\
\hline Improved & 02 & 33.33 & 04 & 66.37 \\
\hline Unchanged & 02 & 33.33 & 02 & 33.33 \\
\hline URETERIC STONE & 04 & & 03 & \\
\hline Cured & 02 & 50.00 & 00 & 00.00 \\
\hline Markedly Improved & 02 & 50.00 & 01 & 33.33 \\
\hline Improved & 00 & 00.00 & 01 & 33.33 \\
\hline Unchanged & 00 & 00.00 & 01 & 33.33 \\
\hline BLADDER STONE & 01 & & 02 & \\
\hline Cured & 00 & 00.00 & 01 & 50.00 \\
\hline Markedly Improved & 00 & 00.00 & & 00.00 \\
\hline Improved & 00 & 00.00 & 00 & 00.00 \\
\hline Unchanged & 01 & 00.00 & 01 & 50.00 \\
\hline
\end{tabular}

In group I (Yavakshara in Paneeya form), out of 10 patients, 6 patients werehaving kidney stone, out of them 2 cured (33.33\%), 2 improved (33.33\%) and 2 unchanged (33.33\%). Ureteric stone was observed in 4 patients, out of them 2 patients cured (50\%) and 2 markedly improved (50\%). Bladder stone was found in 1 patient without any change $(100 \%)$.

In group II (PM Compound) of 10 patients, 6 patients were having kidney stone, out of them 4 improved (66.67\%), 2 unchanged (33.33\%).Ureteric stone was found in 3 patients. Out of them 1 markedly improved (33.33\%), 1 improved (33.33\%), 1 unchanged (33.33\%). Bladder stone was found in two patients. Out of them 1 cured (50\%), 1 unchanged (50\%).

Table -19 : Overall Effect of therapy on 20 patients of Renal calculi.

GROUP I GROUP II

\begin{tabular}{|c|c|c|c|c|}
\hline RESULTS & No. of Pts. & \% Relief & No. of Pts. & \% Relief \\
\hline Cured & 04 & 40.00 & 01 & 10.00 \\
\hline Markedly Improved & 02 & 20.00 & 01 & 10.00 \\
\hline Improved & 02 & 20.00 & 04 & 40.00 \\
\hline Unchanged & 02 & 20.00 & 04 & 40.00 \\
\hline
\end{tabular}

The data of the present series reveals that in Group I (Alkalie preparation of barleygiven in Paneeya kshara form) out of 10 patients, 4 patients $(40.00 \%)$ were cured, 2 patients (20.00\%) markedly improved, 2 patients (20.00\%) improved and 2 patients(20.00\%) observed unchanged.

In Group II (PM Compound), out of 10 patients, 1 patient (10\%) was cured, 1 (10.00\%) markedly improved, 4 patients $(40.00 \%)$ wereimproved and 4 patients $(40.00 \%)$ were found unchanged Discussion:

\section{Overall Effect Of Therapy:}

Table indicates that in group I (Alkali preparation of barleygiven inPaneeya kshara form), out of 10 patients $40 \%$ cured, $20 \%$ markedly improved, $20 \%$ improved and 20\% remained unchanged.In group II (PM Compound - standard control), out of 10 patients $10 \%$ cured, $10 \%$ markedly improved, $40 \%$ improved and $40 \%$ 
remainedunchanged.So, it can be concluded that the Group I (Alkali preparation of barley given in Paneeya kshara form) is found tobe more effective in comparison to Group II (PM Compound - standardcontrol).

Probable Mode of Action:Stone might be dissolved due to the Aśmari Bhedana or Aśmariharaproperty of ingredients present in both the drugs.

\subsection{Results:}

Both the drugs were found more effective on Vātaja Aśmari, Moderately effective on Pittaja Aśmari and least effective on Kaphaja Aśmari.

\subsection{Role of Alkali preparation of barley:}

$\square$ Alkali is having Lekhana, Bhedana, Pācana, Śodhana and Tridoshaghnaproperties.

Alkali preparation of Barleyis having $\mathrm{pH} 6.73$, which is about to neutral (7.0). Thus ithelps to neutralize the acidic media and prevents stone formation.Conclusions:

Alkali preparation of Barley (Yavakshara) possesses the

Properties regarding to disintegration and expulsion of stones and can produce total relief in sign and symptoms of Renal Calculi which proves that it is an ideal preparation for the management of Renal Calculi.

\section{Conclusion Of The Study:}

-The study suggested the age group of 3rd and 4th decades are more proneto disease Renal Calculi. -Male are more prone to Renal Calculi than females.

-Socio-economic status of the patients indicate that maximum (46.43\%)of the patients were from lower middle class.

-Majority of the patients (53.57\%) were vegetarian

-Majority of the patients $46.43 \%$ were having Vāta-kaphaja Prakṛti, whichsupports that Vāta and Kapha plays an important role in Calculiformation

-Maximum number of patients $(88.89 \%)$ were having stone's size $>0.5 \mathrm{~cm}$. The maximum numbers of patients (57.14\%) were having kidney stone.

-Majority of the patients (64.29\%) were having Vātaja Aśmari, while67.86\% of patients were having incidence of single stone.

-Maximum number of patients $(88.89 \%)$ were having stone's size $>0.5 \mathrm{~cm}$. The maximum numbers of patients $(57.14 \%)$ were having kidney stone.

-Majority of the patients (64.29\%) were having Vātaja Aśmari, while67.86\% of patients were having incidence of single stone.

-Haematological and biochemical investigations reveals that both groupshaving statistically non-significant effect on all the parameters. However, it was noticed that the variation in all the parameters were observedwithin normal range.

-Alkali preparation of Barleygiven in Paneeya kshara form is having better results in expulsion of Renal Calculi and decrease in size.

-Both the drugs were found more effective on Vātaja Aśmari. Moderatelyeffective on Pittaja Aśmari and least effective on Kaphaja Aśmari

-InAlkali preparation of Barleygiven in Paneeya kshara form group, high cure rate was observed in kidney stone, whereas in (PM Compound-Standard Control Group) good cure ratewas observed in kidney and ureteric stone.

-Overall effect of therapy shows that inAlkali preparation of barleygiven in Paneeya kshara form group --- 40\% of patients were cured, $20 \%$ markedly improved, $20 \%$ improved and $20 \%$ remained unchanged.

-InPM Compound (Standard Control Group), $10 \%$ patients werecured, $10 \%$ were markedly improved, $40 \%$ improved and $40 \%$ remainedunchanged.

-So, here it can be concluded thatAlkali preparation of barley given in Paneeya kshara form possesses the properties regarding to disintegration and expulsion of stones and can produce total relief in sign and symptoms of Renal Calculi which proves that it is an ideal preparation for the management of Renal Calculi.

After this Clinical Study, entitled "A COMPARATIVE CLINICAL STUDY ON RENAL CALCULI - AN AYURVEDIC PERSPECTIVE" it put light on following conclusions:

1] Alkali preparation of Barleygiven in Paneeya Kshara form is a Classical remedy for Renal Calculi mentioned by Ancient Acharyas.

2] Alkali preparation of Barleygiven in Paneeya Kshara form is very effective in reducing stone size as well as helps in expulsion of the stone from the body.

3] Further Evaluation of this drug is still required for assessing the Side effects \&exact mode of action on Large Sample. 
4] The formulation can be prepared by the Pharmaceutical companies with due Standardization in its preparation for obtaining still better effect on the condition.

Finally, it can be concluded without hesitation, the formulation "Alkali preparation of Barley" is Very Effective in the Management of Renal calculi.

\section{Acknowledgement:}

I Offer my Prayers to Tirupati Lord Venkateshwara and Goddess Padmavathi for showering Blessings and Empowering me to do this Clinical Study without impediments and enabled me to be what I am today.

It is a great pleasure for me to express my deep gratitude to my Highly Respected Guide \& H.O.D

Dr. S. DattatreyaRao M.D. Ph.D. M.Sc.(Psy), Professor, PG Dept. of ShalyaTantra-Ayurvedic General Surgery, S.V.Ayurveda medical College, Tirupati for providing me invaluable guidance, support, love \& thought provoking ideas in every stage of this Study.

It is my duty to thank with Profound sense of respect to my Elder Brother Dr. K.V. Nagendra Prasad, M.S. (General Surgery), Assistant Professor, Kurnool Medical College,Kurnool for continued encouragement, love, affection \& valuable suggestions.

\section{AYURVEDIC BOOKS:}

\section{References:}

[1] AstangHridya -Sarvangasundara Commentary- by Arundatta

[2] BhavaPrakasha - Vidyotini Hindi Commentary - by Pt. ShriBrahmashankar Mishra

[3] CharakaSamhita - Ayurveda Dipika commentary by Chakarpani

[4] Rasatrangani - By Sharma S. MotilalBanarsidas Varanasi

[5] SharangdharSamhita - With Krishana commentary by AcharyaShriRadhakrishanaParasher

[6] SushrutaSamhita - NibandhaSangraha, commentary byDalhana

\section{MODERN BOOKS:}

[1] A synopsis of radiology and imaging - Sorab J. Sidhva

[2] Anatomy and Physiology in health and illness - Ross and Wilson (8th edition)

[3] Anatomy and Physiology for nurses and students of Human Biology - W. Gordon Sers and R. S. Winwood (5th edition)

[4] Aids to Radiological differential diagnosis - Stephen Chapman, RichardNakielny

[5]. A Global text book of Radiology - Holger Patterson M.D.

[6] A guide to Radiological procedures - Stephen Chapman, Richard Nikielny

[7] Clinical methods in Surgery including differential diagnosis - By S. Das

[8] Dorland's Pocket Medical Dictionary - Oxford \& IBH publishing co.

[9] Diagnostic imaging - Armstong

[10] Diagnostic Ultrasound - C.M. Rumack, Stephanil R. Wilson

[11] Essentials of surface \& Radiological Anatomy - V. Kapur, R.K.Suri

[12] Exercises in Radiological diagnosis - Pankaj Joshi, CeeiliaFreed.

[13] General Sonography a Clinical guide - (Beth Ander hub)

[14] Handbook of Surface \& Radiological Anatomy - N.C. Gupta, S.C.Gupta

[15] Human Physiology - C.C. Chatterji

[16] Manual of Radiographic interpretation for general practitioner -By W.H.O

[17] Manual of diagnostic Ultrasound - P.E.S Palmer by W.H.O.

[18] Pocket Atlas of Radiographic Anatomy - Torsten B. Moller, Emil Reif

[19] Principles of Urology - Cambell

[20] Radiological study \&imagings - Bhabejankaria

[21] Radiographic position and Radiologic procedures - P.W.Ballinger

[22] Radiological Secrets - Douglas S. Katz, Staurt A. Groskin

[23] Radiology (Pocket reference)What to order when - Ronald L.Eisenberg, Alexander R. Margulis.

[24] Radiology and imaging for medical students - David Sutton (6thedition)

[25] Short Practice of Surgery - Bailey and Love's

[26] Standard illustrated Dictionary (Anglo-Hindi) - Bhargava's

[27] Text book of Radiology and Imaging - David Sutton.

[28] Text book of Radiology and Imaging - Grainger \& Allison.

[29] Text book of diagnostic Ultrasonography - Sanders, L. Hagen, Ansert.

\section{Thesis}

[1] Role of Punarnava in Mutrashmari, M.D. Thesis G.A.University, Gujarat, India. -CheterjiRekha, 1985

[2] Role of Indigenous drug compound in Mutrashmari, M.D. Thesis, G.A.UUniversity, Gujarat,India. - Ramesh Chand Sharma, 1994

[3] Role of Sunthyadikwatha in the management of Mutrashmari, M.D. Thesis, G.A.UUniversity, Gujarat,India. - Venkata R. Naidu, 1994.

[4] Role of Punarnavadi compound in the management of Mutrashmari, M.D. Thesis, G.A.UUniversity, Gujarat,India. - Deepak kulshrestha, 1996

[5] Role of BadarashmaPisti in the management of Mutrashmari,M.DThesis, G.A.U.University, Gujarat,India-DhirajB.Malaviya.,1997 